\title{
DYNAMICS OF LANDSCAPE CHANGE IN A MOUNTAINOUS RIVER BASIN: A CASE STUDY OF THE BHAGIRATHI RIVER, WESTERN HIMALAYA
}

\author{
GAUR, T. ${ }^{1}-$ SINHA, A. ${ }^{1}-$ ADHIKARI, B. S. ${ }^{1}-$ RAMESH, K..$^{1,2^{*}}$ \\ ${ }^{I}$ Wildlife Institute of India, Dehradun 248001, Uttarakhand, India \\ ${ }^{2}$ Faculty of Forestry, University of British Columbia, Vancouver, Canada \\ *Corresponding author \\ e-mail: ramesh@wii.gov.in; phone: +91-941-297-1678 \\ (Received $27^{\text {th }}$ Feb 2019; accepted $1^{\text {st }}$ May 2019)
}

\begin{abstract}
Riverine systems are influenced by historical and current land use practices linked to alterations in the riparian zone across multiple scales. This study aims to explore the trend of spatiotemporal land cover changes and configuration along a major headstream of the river Ganges in India. Geo-spatial tools were used to quantify the changes in the landscape across a time span of 22 years. Landscape configuration was quantified by applying class level metrics using the software FRAGSTATS. A loss of $18.3 \%$ and $5.5 \%$ in the dense forest class was perceived in the upland and the riverine areas respectively aided by conversion of large contiguous forests into smaller isolated patches. Markov analysis showed that the forests in the landscape still possess inherent resilience capacity as indicated by a probability of $47 \%$ conversion of open forest class to dense forest class in future based on current land-use practices. Land cover changes and forest fragmentation can have inevitable impacts on ecological functioning and species persistence. Monitoring these changes is fundamental in planning future strategies for riverine landscape management. The present study underpins the utility of remote sensing and GIS in building useful baseline data for inaccessible mountainous landscapes at both local and regional scales.

Keywords: Bhagirathi basin, fragmentation, landscape change, landscape-level assessment, riverine landscape
\end{abstract}

\section{Introduction}

Natural riverine landscapes are classic examples of ecotonal habitats characterized by a high level of heterogeneity. Multiple interactive pathways operating across various spatiotemporal scales determine the dynamic structure and function of these terrestrialaquatic continuum habitats (Steel et al., 2010). River form linear corridor features in the landscapes they traverse; montane river systems characteristically being single-thread channels bordered by a narrow band of native riparian vegetation (Ward et al., 2002). Riverine forests grow along the riverbanks and their structural composition is unique and highly influenced by the river's fluvial activities (Naiman et al., 1993). They provide multiple ecosystem services (Tomscha et al., 2017; Sutfin et al., 2016); providing habitats to diverse organisms (Dybala et al., 2019) and maintaining a network of dispersal corridors (Naiman et al., 2005). Riverine forests support high densities and diversities of migratory birds by providing a critical habitat and the only edge cover available to them during migration (Naiman et al., 1993; Gergel et al., 2007).

Forests are losing their resilience capacity at an increasing rate, often irreversibly due to large-scale changes occurring at an unprecedented rate (Wilson, 1992). Forest fragmentation is a global concern, effects of which are well documented in climatic, biophysical and hydrological cycles (Ramanathan et al., 2005), biodiversity and associated ecosystem services (Xu et al., 2009). Fragmentation has impacts on the overall health of the 
forest ecosystem. Forest loss and changes in forest configuration impedes the survival of the forest dependent species (Villard et al., 1999; Bogaert et al., 2011). India is endowed with a forest cover of $21.34 \%$ (FSI, 2015) of its total landmass and is ranked tenth in the world in terms of the extent of forest cover (FAO, 2010). Although, escalating human population is increasing dependence on forested landscapes for space and resources leading to the degradation of forests, fragmentation being a major corollary (Roy and Roy, 2010). In the state of Uttarakhand, anthropogenic pressure has led to dwindling of forest cover with a loss of $268 \mathrm{~km}^{2}$ area in a span of two (2013-2015) years (FSI, 2015) with individual case studies from different districts providing strong evidences in the same line (Rawat and Kumar, 2015; Rawat et al., 2013).

Hence, it is critical to assess the current condition of vegetation in a landscape for its conservation and designing future restoration programs (Egbert et al., 2002; He et al., 2005). Discerning the patterns of vegetation change within a landscape can provide a basis for future monitoring and addressing its management (Gould, 2000). Remote sensing offers the best tool to analyze, map, and monitor ecosystem patterns and processes. It facilitates possible data archives from present time to over several decades back due to its potential for observing the Earth's surface at different times (Ety and Rashid, 2019; Xie et al., 2008). Change is an inherent characteristic of a landscape driven by natural and anthropogenic drivers shaping its structure, function and dynamics. Detecting change is an important aspect for studying landscapes that are dynamic and continuously changing, where change is 'an alteration in the surface components of the vegetation cover' (Milne, 1988) or 'a spectral/spatial movement of a vegetation entity over time' (Lund, 1983).

This study aims to explore the use of geo-spatial tools in monitoring landscape changes for inaccessible areas in mountainous terrains across spatial and temporal scales. Advanced tools like FRAGSTATS (McGarigaI and Marks, 1994; Neel et al., 2004) and simulation models using Markov analysis were used to understand patterns of forest fragmentation and predicting future scenarios in the backdrop of current land-use patterns. The study is intended to a comparative understanding of Land-Use and Land-Cover (LULC) change and forest fragmentation events in riverine stands in contrast to the entire river basin.

\section{Materials and methods}

\section{Study area}

The river Ganga is the largest and longest river of India and a lifeline to millions of humans (supporting $>40 \%$ of the total population; sustaining 520 people per sq. $\mathrm{km}$ ) (Census of India, 2001). It is also listed among 'the top 10 rivers of the world at risk' because of over-extraction of water resources (Wong et al., 2007). The mountainous catchment of the river Ganga is formed by the two Himalayan rivers - the Bhagirathi and the Alaknanda. The study area i.e. the Bhagirathi basin spreads across three administrative districts of Garhwal region viz., Tehri, Pauri, and Uttarkashi in the state of Uttarakhand, Western Himalaya (Fig. 1). We focused our study along the river stretch between Gaumukh, the origin of the Gangotri glacier $\left(30^{\circ} 55^{\prime} 37.35^{\prime \prime} \mathrm{N}\right.$ lat. and

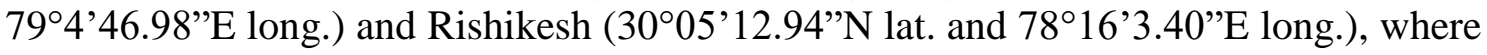
the river enters the plains encompassing an elevational range of 4100 to $330 \mathrm{~m}$ above sea level. Due to enormous hydro-power potential, many operational and proposed hydro-electric projects exist enroute the Bhagirathi River (Rajvanshi et al., 2012). The characteristic species representing various vegetation types include Shorea robusta, Mallotus philippensis, Acacia catechu, Bauhinia variegata, Toona ciliata, Celtis 
australis, Pinus roxburghii, Alnus nepalensis, Pinus wallichiana, Populus ciliata, Cedrus deodara and Betula utilis in association with a large number of shrubs and herbaceous flora. The climate of the state of Uttarakhand is primarily temperate except for the plains, with temperatures ranging from below 0 to $43{ }^{\circ} \mathrm{C}$ with an annual rainfall of $1550 \mathrm{~mm}$ (Government of Uttarakhand, 2014).

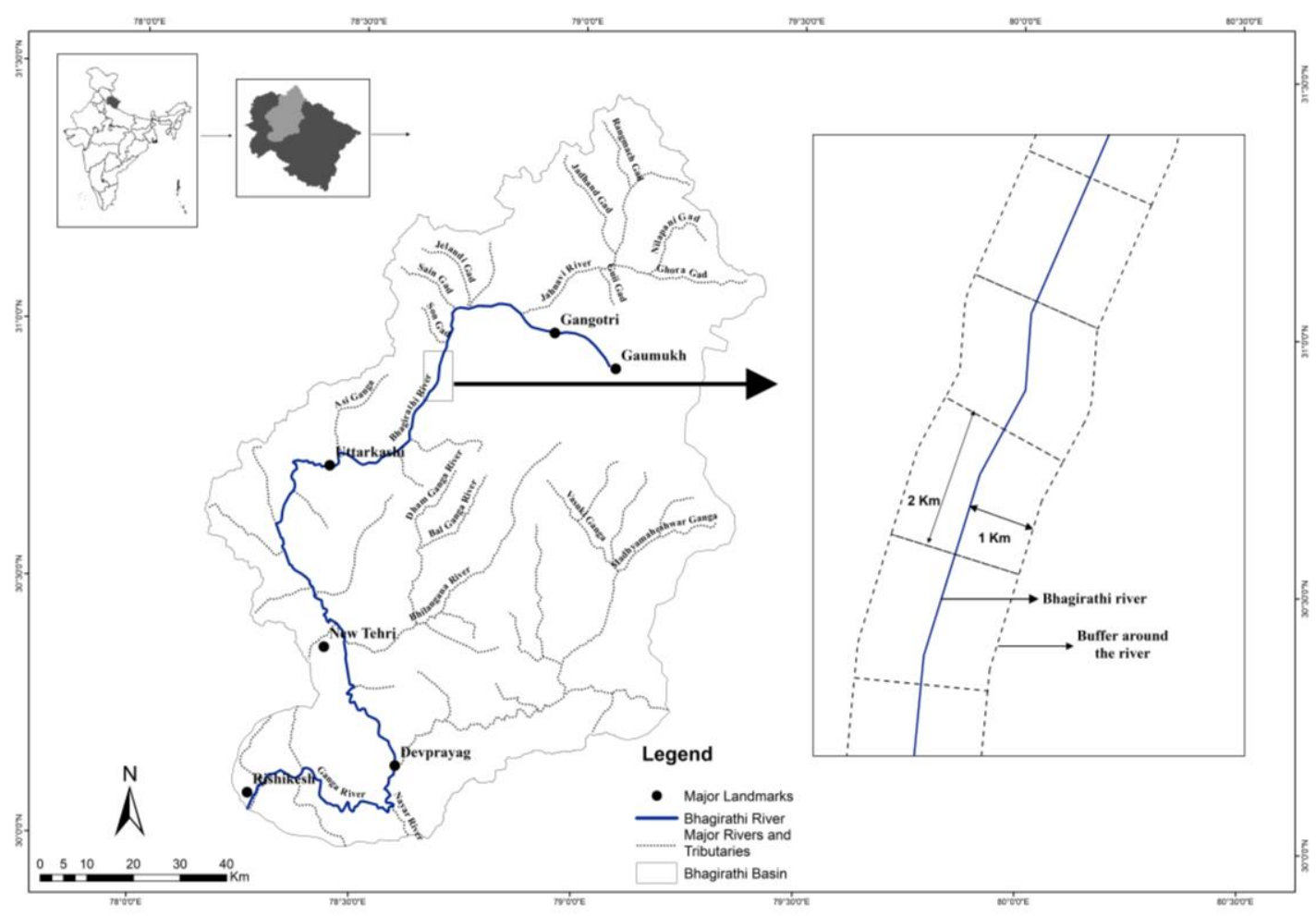

Figure 1. Location of Bhagirathi river basin in the state of Uttarakhand in India and diagrammatic sketch (right side) represents the cross-section of riverine buffer (2 km long and $1 \mathrm{~km}$ wide) on either side along the Bhagirathi river

\section{Data procurement and processing}

Past studies on LULC changes have been carried out by using remote sensing data sets (Halmy et al., 2015), such as MODIS (Alhamdan et al., 2017), Landsat (Osgouei and Kaya, 2017) and SPOT (McCarthy et al., 2018). Since, Landsat offers optimum spatial and spectral resolutions and multi-temporal archives to understand the changes over space and time, it is best suited for this study. Cloud-free Landsat satellite data of $30 \mathrm{~m}$ spatial resolution was downloaded from USGS Earth Explorer (www.earthexplorer.usgs.gov) for the month of May for the years 1993 and 2015. The imageries of the path and row 146/38 and 146/39 were subsequently mosaiced for further image interpretation (Table 1). Preprocessing was performed in Erdas Imagine 2013 and ArcGIS 10.1 before classifying the images, including radiometric correction and topographic normalization. Normalization algorithms aided in removing albedo variations and topographic effects associated with remote sensing data acquired for mountainous regions. To remove topographic effects resulting from the position of the sun and angle of terrain, an algorithm called Minnaert correction was used (Allen, 2000; Ge et al., 2008). 
Table 1. Details of the Landsat satellite images used as the primary dataset for spatiotemporal LULC change analysis and forest fragmentation

\begin{tabular}{|c|c|c|c|c|c|}
\hline \multicolumn{3}{|c|}{ Landsat 5 (1993) } & \multicolumn{3}{|c|}{ Landsat 8 (2015) } \\
\hline Bands & $\begin{array}{c}\text { Spectral } \\
\text { resolution }(\mu \mathrm{m})\end{array}$ & $\begin{array}{c}\text { Spatial } \\
\text { resolution }(\mathrm{m})\end{array}$ & Bands & $\begin{array}{c}\text { Spectral } \\
\text { resolution }(\mu \mathrm{m})\end{array}$ & $\begin{array}{c}\text { Spatial } \\
\text { resolution }(\mathbf{m})\end{array}$ \\
\hline B1-Blue & $0.45-0.52$ & 30 & B1- Coastal & $0.43-0.45$ & 30 \\
\hline B2- Green & $0.52-0.60$ & 30 & B2- Blue & $0.45-0.51$ & 30 \\
\hline B3- Red & $0.63-0.69$ & 30 & B3- Green & $0.53-0.59$ & 30 \\
\hline $\begin{array}{l}\text { B4- NIR (Near } \\
\text { infrared) }\end{array}$ & $0.76-0.90$ & 30 & B4- Red & $0.64-0.67$ & 30 \\
\hline $\begin{array}{l}\text { B5- MIR } \\
\text { (Middle } \\
\text { infrared) }\end{array}$ & $1.55-1.75$ & 30 & $\begin{array}{l}\text { B5- NIR (Near } \\
\text { infrared) }\end{array}$ & $0.85-0.88$ & 30 \\
\hline $\begin{array}{l}\text { B6- Thermal } \\
\text { infrared }\end{array}$ & $10.40-12.50$ & 120 & $\begin{array}{l}\text { B6- SWIR } 1 \\
\text { (Short wave } \\
\text { infrared) }\end{array}$ & $1.57-1.65$ & 30 \\
\hline \multirow[t]{5}{*}{$\begin{array}{l}\text { B7- MIR } \\
\text { (Middle } \\
\text { infrared) }\end{array}$} & $2.08-2.35$ & 30 & $\begin{array}{l}\text { B7- SWIR } 2 \\
\text { (Short wave } \\
\text { infrared) }\end{array}$ & $2.11-2.29$ & 30 \\
\hline & & & $\begin{array}{c}\text { B8- Pan } \\
\text { (Panchromatic) }\end{array}$ & $0.50-0.68$ & 15 \\
\hline & & & B9- Cirrus & $1.36-1.38$ & 30 \\
\hline & & & $\begin{array}{c}\text { B10- TIRS } 1 \\
\text { (Thermal } \\
\text { infrared sensor) }\end{array}$ & $10.6-11.19$ & 100 \\
\hline & & & $\begin{array}{c}\text { B11- TIRS } 2 \\
\text { (Thermal } \\
\text { infrared sensor) }\end{array}$ & $11.5-12.51$ & 100 \\
\hline
\end{tabular}

A reconnaissance field survey was undertaken before classifying the image and ground truth points were collected during subsequent field surveys across the entire river basin. Processed False Color Composite (using the spectral band combination of Near-infrared, Red and Green) for the years 1993 and 2015 were classified using unsupervised classification (ISODATA technique) beginning with 100 classes and then decreasingly grouping together into eight land cover classes namely, dense forest, open forest, shrubland, grassland, agriculture, barren land, river and snow. To validate the remotely sensed data, ground truth points were gathered from on ground surveys and Google Earth generated points to improve accuracy of classified LULC images. The classification accuracy for the images of the two years was measured using the agreement between predicted and observed (field validation points) categories of a dataset, while correcting for agreement that occurs by chance (Jenness and Wynne, 2005). It made use of overall accuracy (OA) of the model in terms of both predictive model and field surveyed sample points, to correct for chance agreement between the both. Around 270 ground truth points collected through extensive field surveys aided in improving the classification accuracy.

\section{Landscape configuration and temporal change}

We calculated the area under the eight land cover classes in ArcGIS 10.1 to understand current landscape configuration of the Bhagirathi river basin along with 
temporal change across a period of two decades. Markov chain prediction using IDRISI GIS Analysis in TerrSet software was performed to develop the probability matrix for future transitions resulting from the cross-tabulation between the earlier and later times' land cover images. This matrix calculates the probability of a given class pixel to change into any other class or stay the same in the next time period. In a Markov Chain transition, the probability $\left.p_{(} y_{t}\right)$ that a phenomenon exists in state $a_{j}$ if it was in state $a_{i}$ at a previous time is denoted by the following equation:

$$
p\left\langle y_{t}=a_{i} \mid y_{t-1}=a_{i}\right\rangle
$$

A landscape is characterized by various land-use and land-cover configurations which is dynamic over time, hence depicts a Markov Chain matrix that encapsulates multiple transitions:

$$
\underline{P}=\left[p_{i j}\right]=\left[\begin{array}{c}
p_{11}, p_{12} p_{1 n} \\
p_{21,} p_{22} p_{2 n} \\
p_{n 1} p_{n 2} p_{n n}
\end{array}\right]
$$

where $\underline{P}=\left[p_{i j}\right]$ is the probability of transitioning from one state $i$ to a different state $j$ or to multiple states $\left(i_{1}, i_{2}, \ldots i_{j}\right)$ (Wilson et al., 2018).

FRAGSTATS 4.2.1 was used to quantify the spatiotemporal changes in the structural characteristics reflecting the ecological process and consequent pattern in the landscape. We used class-level metrics to understand the status of forested areas at two scales, for the entire landscape and the riverine buffer (considering a distance of $1 \mathrm{~km}$ on either side). We investigated the change in forest class across the landscape using patch density (PD), largest patch index (LPI) and percentage of the landscape (PLAND) under the patch area metrics, the area of the patch (AREA MN) under the shape metrics, clumpiness index (CLUMPY) and aggregation index (AI) under the interspersion metrics. PD is expressed as the number of patches on a per unit area basis and is considered as general index of spatial heterogeneity of the entire class in a landscape mosaic. LPI at the class level quantifies the percentage of total landscape area comprised by the largest patch and is a simple measure of dominance. PLAND quantifies the proportion of particular patch type of a class in a landscape and approaches zero when the class becomes increasingly rare in the landscape. Area $\mathrm{MN}$ or mean patch size is a measure of fragmentation in a landscape as the smaller the mean patch size the more fragmented is the focal class in a landscape. Both AI and CLUMPY are calculated from adjacency matrix which means a single, compact patch type is achieved when the AI approaches maximum value while clumpiness index values varies between -1 to +1 indicating maximum disaggregation or aggregation of the focal patch type (McGarigal and Marks, 1995). For further insights regarding changes in the riverine forest stands, we also analyzed patch properties along both the banks of the Bhagirathi river.

A total of 123 units of $2 \mathrm{~km}$ length each were created on the river (linear shapefile) with the aid of the Split tool in ArcGIS10.1 (Fig. 1). Thereafter, the Buffer tool was used to create a buffer of $1 \mathrm{~km}$ width on both sides of the river. Hence, we created 123 segments of $2 \mathrm{~km}^{2}$ area on both sides of the river for performing FRAGSTATS analyses in the riverine buffer. With a special focus on understanding the pattern of forest fragmentation in these narrow linear habitats, we used class-level FRAGSTATS analyses. Metrics used for this analysis were identical to those used for comprehending spatiotemporal pattern of forest structure in the entire landscape for enabling a comparative understanding. 


\section{Results}

\section{Landscape configuration and temporal change}

The entire river basin comprised of a total area of $11389 \mathrm{~km}^{2}$. The overall accuracy of the classified images for the years 2015 and 1993 were $85.1 \%$ and $87.2 \%$, respectively. The LULC pattern for the year 2015 indicated $24.1 \%$ of the land under dense forest class followed by, open forest $(24.3 \%)$, shrubland (3.1\%), grassland $(5.6 \%)$, agriculture land (4.5\%), barren land $(7.1 \%)$, river $(0.6 \%)$ and snow cover $(30.6 \%)$. The dense forest markedly declined (18.3\%) across the time span of 22 years, although the overall area under forests has relatively not undergone much change (Table 2). The open forest class showed an increase $(18.3 \%)$ in the entire river basin. Agriculture class (increase of $2.5 \%$ ) was found uniformly distributed in the entire landscape barring higher altitudes with a significant concentration along the rivers (Fig. Al in the Appendix; Table 2). The buffer of a width of $1 \mathrm{~km}$ encompassing an area of $409.9 \mathrm{~km}^{2}$ varied in composition, although it reflected almost similar trends of landscape change as of the entire basin (Table 2).

Table 2. An area-wise comparative analysis of spatiotemporal change (increase depicted as positive [+] and loss as negative [-]) of land cover between 1993 and 2015 in Bhagirathi basin (total area $=11389 \mathrm{~km}^{2}$ ) and $1 \mathrm{~km}$ buffer along both the sides of Bhagirathi river (total area $\left.=490.9 \mathrm{~km}^{2}\right)$

\begin{tabular}{|c|c|c|c|c|c|c|}
\hline \multirow{3}{*}{ Land cover class } & \multicolumn{3}{|c|}{ Basin } & \multicolumn{3}{|c|}{ Buffer } \\
\hline & \multirow{2}{*}{$\begin{array}{c}1993 \\
\text { Area }\left(\mathrm{km}^{2}\right)\end{array}$} & \multirow{2}{*}{$\begin{array}{c}2015 \\
\text { Area }\left(\mathrm{km}^{2}\right)\end{array}$} & \multirow{2}{*}{$\%$ Change } & 1993 & 2015 & \multirow{2}{*}{$\%$ Change } \\
\hline & & & & Area $\left(\mathbf{k m}^{2}\right)$ & Area $\left(\mathbf{k m}^{2}\right)$ & \\
\hline Dense forest & 4830.9 & 2746.2 & -18.3 & 201.7 & 174.7 & -5.5 \\
\hline Open forest & 683.8 & 2768.1 & 18.3 & 55.9 & 109.7 & 11.0 \\
\hline Shrubland & 508.4 & 358.7 & -1.3 & 59.8 & 7.9 & -10.6 \\
\hline Grassland & 672.8 & 636.4 & -0.3 & 67.7 & 52.7 & -3.1 \\
\hline Agriculture & 226.2 & 507.7 & 2.5 & 15.1 & 45.9 & 6.3 \\
\hline Barren land & 1136.7 & 814.2 & -2.8 & 62.2 & 54.3 & -1.6 \\
\hline Snow & 3282.0 & 3486.9 & 1.8 & 3.8 & 5.0 & 0.2 \\
\hline River & 48.5 & 70.8 & 0.2 & 24.8 & 40.8 & 3.3 \\
\hline
\end{tabular}

The study area depicted a decline in dense forest areas across the entire Bhagirathi basin $\left(4830.9 \mathrm{~km}^{2}\right.$ to $\left.2746.2 \mathrm{~km}^{2}\right)$ as well as in the riverine buffer $\left(201.7 \mathrm{~km}^{2}\right.$ to 174.7 $\mathrm{km}^{2}$ ) (Table 2). There was a substantial increase in the open forest class in both buffer areas and entire basin, whereas shrubland decreased significantly in the riverine buffer (10.6\%). The area under river class increased markedly from $48.5 \mathrm{~km}^{2}$ (1993) to 70.8 $\mathrm{km}^{2}$ (2015) owing to land submergence by the Tehri dam, which became operational in the year 2008 and is conspicuous in the map (Fig. Al). Area under shrubland and grassland categories decreased across time, remarkably in the riverine buffer (Shrubland-10.6\%, Grassland-3.1\%). Agricultural land increased across the entire basin, comparatively more in the riverine areas. The riverine buffer units (Fig. 2; Table Al in the Appendix) depict the similar trends where dense forest showed mostly a negative change while open forest and river showed a positive change across a span of 22 years. 


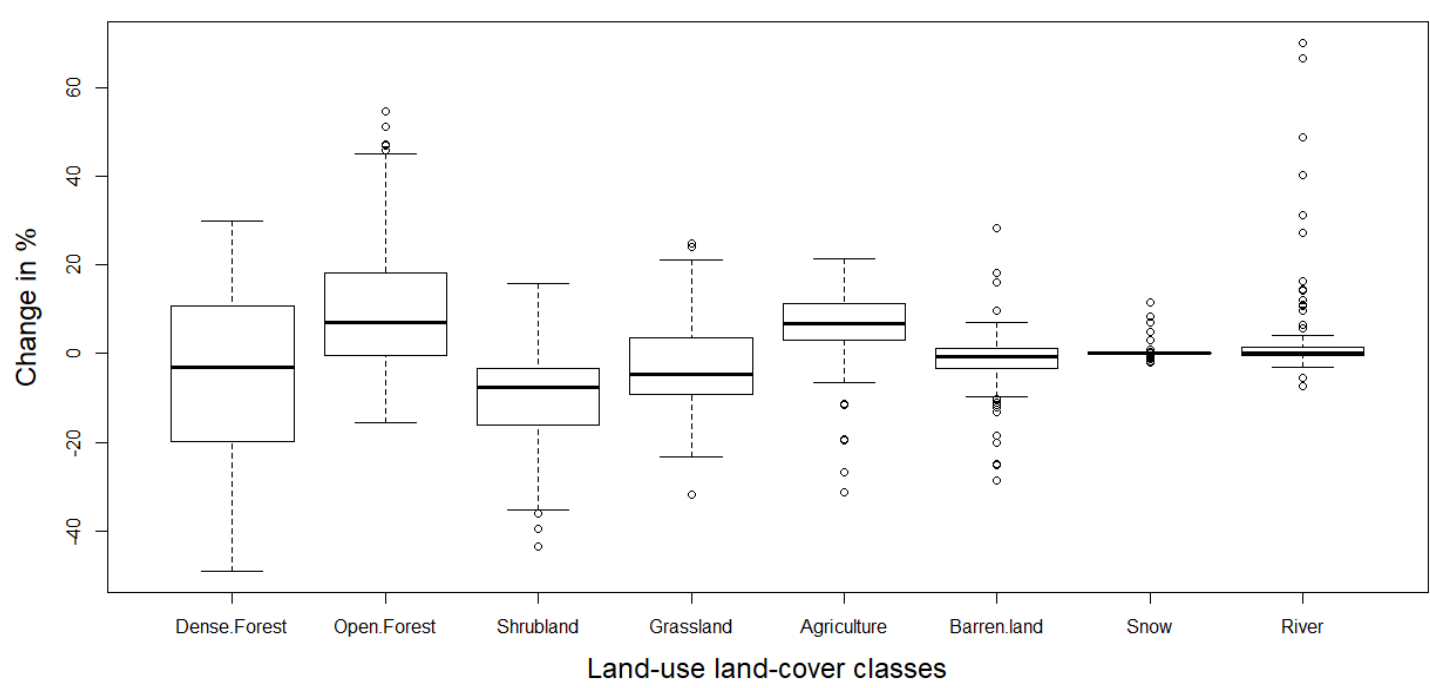

Figure 2. Box and whisker plot illustrating the area-wise percentage change of Land use/Land cover categories from the years 1993 to 2015 in the 123 riverine buffer units ( $4 \mathrm{~km}^{2}$ area) along both the banks of the Bhagirathi River

Results of Markov analysis reveal that areas under open forest in the entire Bhagirathi basin still hold an equal probability (0.47) of reverting back to dense forest and vice-versa by the year 2037 (Fig. 3) depending on the current land-use practices. Area under grassland showed a significant probability of getting converted into open forest $(40 \%)$. The probabilities of shrubland getting converted to open forest and viceversa are comparatively similar and smaller in magnitude, while the probability of desertification (conversion of open forest into barren land) was found to be negligible $(2 \%)$.

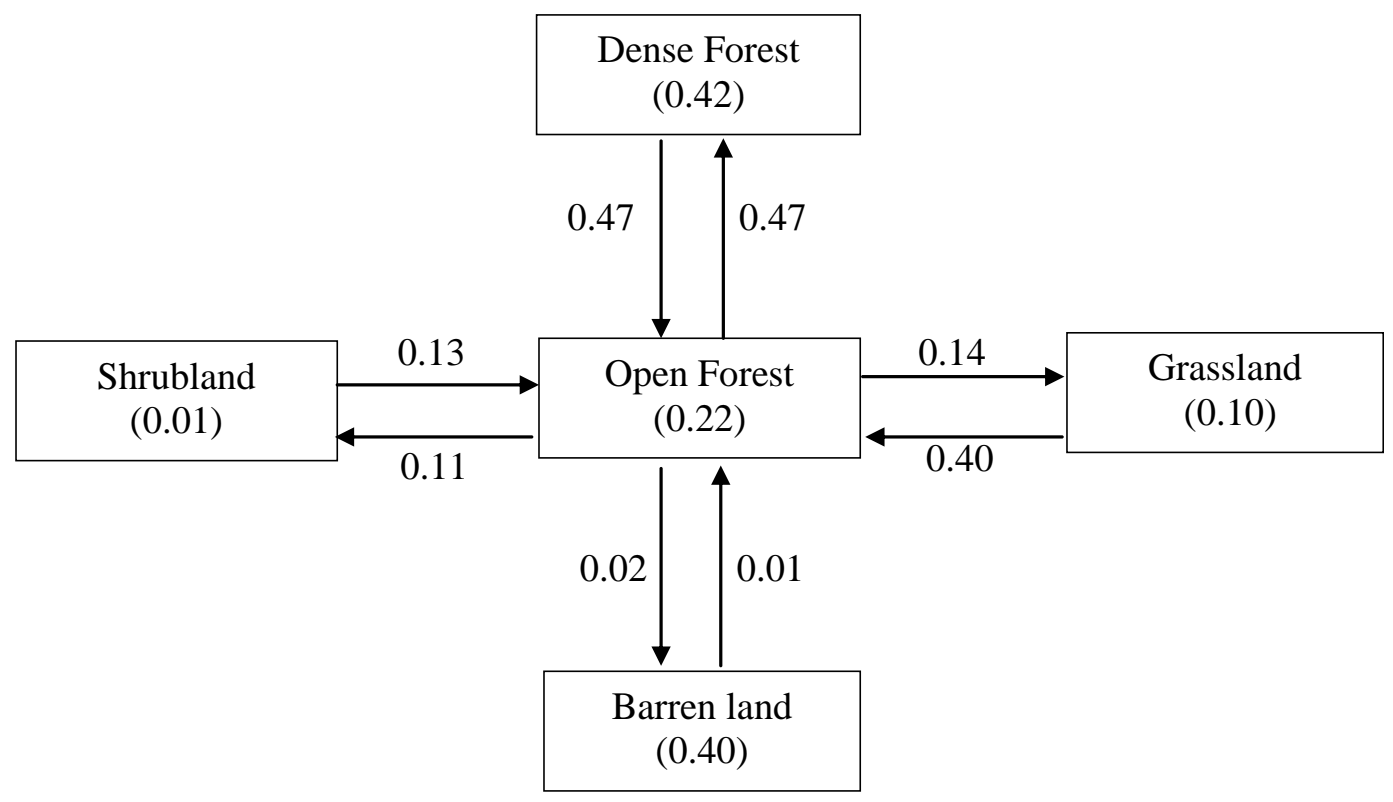

Figure 3. Land cover/Land use transition probabilities as predicted for the year 2037 (22 years) using Markov analysis (values within box denotes self-replacement probability and values on arrows are their transition probabilities to other land-cover classes) 


\section{Forest integrity and intactness}

Results of FRAGSTATS analysis indicate fragmentation events with an increase in the number of patches (1993: 30166 and 2015: 31978) and patch density (1993: 2.65 patches $\mathrm{km}^{-2}, 2015: 2.81$ patches $\mathrm{km}^{-2}$ ) and decrease in the Large Patch Index (LPI; 1993: 46.0\% and 2015: 40.1\%) for the forested areas in the Bhagirathi basin. Patch density is a fundamental aspect of landscape pattern and serves as a general index of spatial heterogeneity of the entire landscape mosaic. LPI essentially quantifies the percentage of total landscape area comprised by the largest patch and is a simple measure of dominance. The river basin has undergone a drastic increase in patch density with decreasing LPI in the basin, indicating the disintegration of existing forest patches into smaller fragments.

Proportion of Landscape (PLAND) values decreased in the dense forest class from $42.5 \%$ (1993) to $24.1 \%$ (2015) while simultaneously increasing in the open forest class from $6.0 \%$ to $24.3 \%$, providing evidence for the process of conversion of dense forest to open forest (Table 3). Values for Aggregation Index (AI) has decreased moderately in the dense forest type indicating decrease in intactness. In contrary, AI values increased for the open forest class hinting towards decreasing distance between neighbouring patches of this class. The overall status of forests in the Bhagirathi basin portrayed more patchiness in the dense forest class with patches of open forest getting clustered together with time.

Table 3. Comparative analysis of forest fragmentation using class metrics (dense forest and open forest) between the years 1993 and 2015 in the Bhagirathi basin

\begin{tabular}{c|c|c|c|c|c|c|c|c}
\hline $\begin{array}{c}\text { Forest } \\
\text { type }\end{array}$ & Year & $\begin{array}{c}\text { PLAND } \\
(\boldsymbol{\%})\end{array}$ & NP & $\begin{array}{c}\text { PD (number of } \\
\text { patches/km } \mathbf{k}^{\mathbf{2}}\end{array}$ & LPI (\%) & $\begin{array}{c}\text { AREAMN } \\
\left.\mathbf{( k m}^{2}\right)\end{array}$ & CLUMPY & AI (\%) \\
\hline \multirow{2}{*}{ Dense } & 1993 & 42.49 & 44952 & 3.96 & 34.44 & 10.74 & 0.82 & 89.92 \\
& 2015 & 24.12 & 119856 & 10.43 & 1.9 & 2.29 & 0.65 & 73.4 \\
\hline \multirow{2}{*}{ Open } & 1993 & 6.02 & 109691 & 9.66 & 0.01 & 0.62 & 0.47 & 50.22 \\
& 2015 & 24.31 & 60486 & 5.32 & 4.41 & 4.57 & 0.68 & 75.65 \\
\hline
\end{tabular}

NP: Number of Patches, PD: Patch Density, LPI: Large Patch Index, PLAND: Proportion of Landscape, AREA MN: Area Mean: CLUMPY: Clumpiness Index, AI: Aggregation Index

Although it is useful to consider forest fragmentation at the landscape level, the quality of the forest is best realized when focusing on a single habitat type i.e. smaller geographic extent. The forest communities along riverbanks are central elements of riverine landscapes undergoing maximum interactions at the terrestrial-aquatic interface. Results of FRAGSTATS analyses for 123 units along both the banks of the Bhagirathi river were noteworthy for the riverine forest cover (Fig. 4). There was minimal change in the patch density in the units 1-3 (Fig. 4) which belong to the highaltitude areas forming treeline, consisting stands of Cedrus deodara which have remained relatively intact temporally. This can be owing to the inaccessibility of these areas due to their remoteness and also because this forested land is protected under the Gangotri National Park. A similar trend exists for units 110-123, which lie around the town of Rishikesh where riverine stands comprise of late successional species like Holoptelea integrifolia and Haldina cordifolia which are well established and less prone to disintegration. Temporal fluctuations in patch density showed spatial patterns with 
three distinct peaks. Increase in patch density in the higher elevation river reaches can be owed to the natural riverine vegetation in this belt (units from 15-30). Forest community here comprises of Alnus nepalensis and Populus ciliata both of which are early successional species and grow well on eroding slopes and open flat sites, respectively. LPI has considerably been constant across the entire riverine stretch (Fig. 4) with a little increase around the submergence zone of Tehri dam followed by an increase in patch density (units around 40-60) depicting the afforestation activities near Tehri dam in an area of $138.4 \mathrm{~km}^{2}$ under Forest Department plantation scheme raised in the year 2010-11.
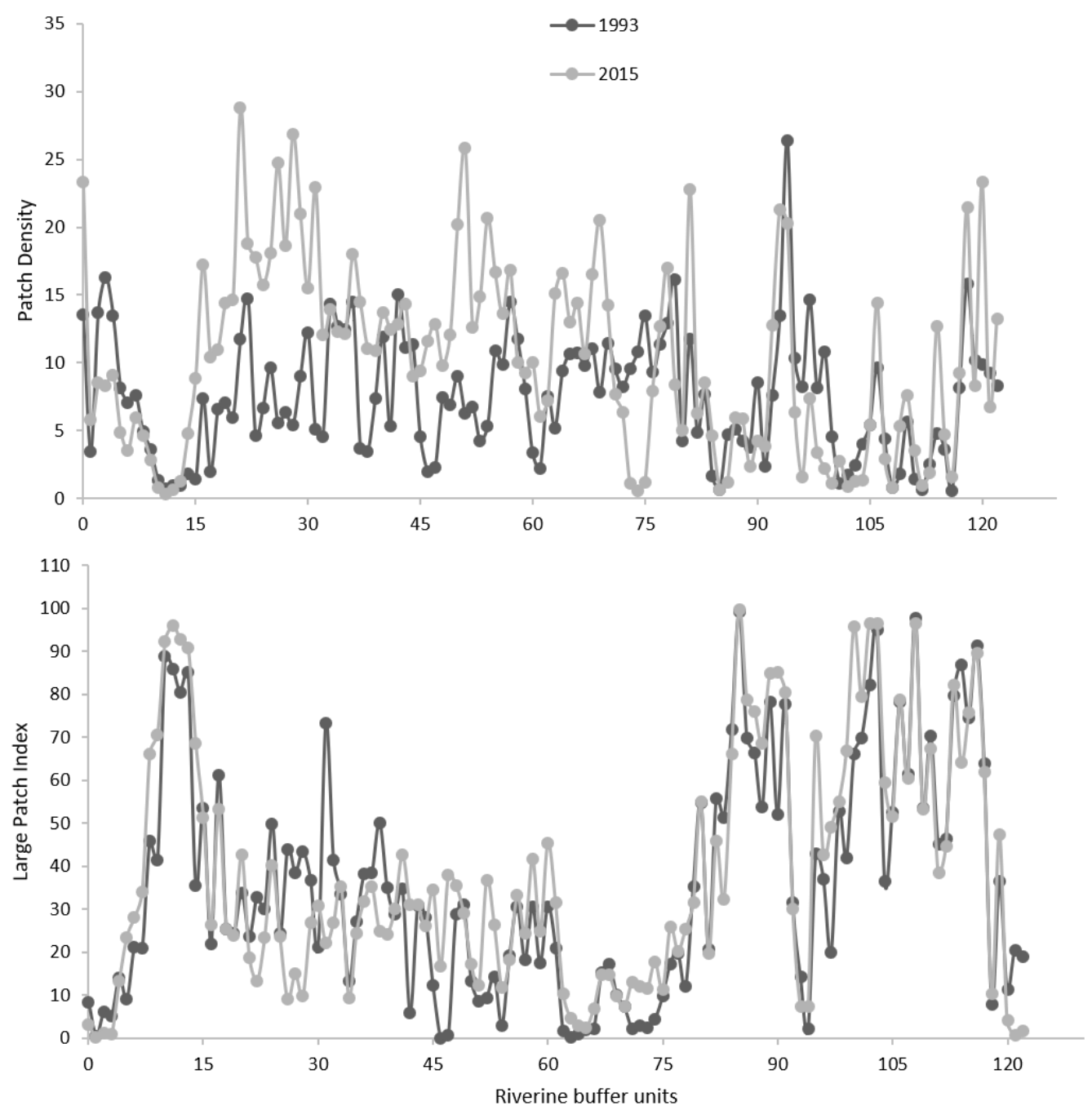

Figure 4. Graphs comparing fragmentation events of the years 1993 and 2015 for two class level indices. (a) Patch density and (b) large patch index for forest class in the 123 riverine buffer units (2 $\mathrm{km}$ long andl $\mathrm{km}$ wide) along both the banks of the Bhagirathi river

\section{Discussion}

Spatiotemporal landscape change has been studied for varied applications including planning and management of urban sprawl (Vani and Prasad, 2019), understanding dynamics of vegetation cover change (Kaur et al., 2019), forest connectivity for wildlife (Areendran et al., 2017) and watershed planning and management (Wilson et al., 2018). 
Riverine landscapes are fragile and dynamic in nature (Miles et al., 2004) and consist of plant species with narrow distribution ranges (Silva et al., 2008) which renders the characteristics of riverine vegetation to be markedly different in structure and function. This makes the riverine ecosystem more vulnerable to extreme events and natural disasters, and thus, an important landscape to understand and manage (Stella and Bendix, 2019). The Himalayan river systems are undergoing major modifications through changes in land use, climate and water resource development (Rajvanshi et al., 2012; Manel et al., 2000). A similar study was found useful for knowledge-based future land management practices in the Upper Awash basin, Ethiopia where river basins and sub-basins were considered as focal area to study the extent and the rate of landscape change (Shawul and Chakma, 2019). Our study is a pioneering attempt of landscapelevel assessment, ascertaining forest fragmentation patterns by select metrics across a time-span of two decades containing a substantial amount of riparian stands, which are otherwise not protected by law (Roy et al., 2013). Results highlight considerable conversion of dense forest into open forest characterized by the proliferation of much smaller, less connected forest patches in the studied landscape. Although rates of forest fragmentation were found to be appreciable, the forests of the landscape exhibited marked resilience capacity as portrayed by the results of the Markov transition probability matrix (Fig. 2). A remote-sensing-based analysis of the forest cover in the Western Himalaya during the years 1985-2005 also indicated significant degradation in the forest cover during two decades as depicted by our study (Roy and Rathore, 2019).

The composition and spatial configuration of the landscape matrix have multiple cascading effects mediated by disproportionate edge and area ratios which can profoundly affect dispersal- colonization dynamics (Dunning et al., 1992; Gascon et al., 1999) and habitat use (Antongiovanni and Metzger, 2005; Norton et al., 2000) of animals. The magnitude of change in select landscape matrices used to quantify patterns of landscape composition and configuration can influence ecological communities dependent on these forest patches (Donovan, 1997; Rodewald and Bakermans, 2006). In our study, the decrease in the LPI in the basin with rise in the number of patches highlights internally driven dynamics within patches themselves (Woodroffe and Ginsberg, 1998; Chen et al., 1995). Results of Fragstats analysis brings forth the fact that patches under the dense forest category are undergoing isolation with time whereas patches of open forest are clumping together (Table 2). Fragmented vegetation reduces overall plant species richness, encourages edge species and discourages interior forest species (Solbrig, 1992), hence modifying the entire structure of communities (Haddad et al., 2015). Intact large patches of natural vegetation persist in areas protected by legal restrictions and forests in inaccessible terrains (high-altitude region) (Fig. 3). In future, patch level analyses can be performed to comprehend the underlying factors that have resulted in the distinct spatial patterns observed in the forest.

The Ganga basin has the highest dam density (1/18 of the river channel being dammed) followed by Brahmaputra $(1 / 35 \mathrm{~km})$ and the Indus $(1 / 36 \mathrm{~km})$ in the Indian Himalayan Region (Pandit and Grumbine, 2012). Due to the development of Tehri dam, Koteshwar hydropower plant and Kotli-Bhel hydropower project (under development in Bhagirathi basin), approximately $68.03 \mathrm{~km}(31 \%)$ of the Bhagirathi river is being diverted, whereas $85.4 \mathrm{~km}^{2}(39 \%)$ of the riverine area has been submerged (Rajvanshi et al., 2012). Dams alter the natural flow of rivers and streams, thus changing the temperature and chemical composition of water which determines the distribution of riverine tree species (Bergkamp et al., 2000). A large number of dams along the course 
of the Bhagirathi river has resulted in modification of the native riverine vegetation owing to altered micro-climatic regimes and afforestation activities by Forest Department around the Tehri region highlighted by an increase in the LPI in this region (Fig. 3). Landslides are common in montane river networks and cause considerable loss to riverine forest stands on a regular basis. Hence, quantifying the landscape change in the riverine buffer is concerning in the backdrop of vulnerability to natural disasters.

Over the last several decades, riverine buffers have been employed as a conservation tool in an attempt to maintain natural processes and functions in running-water ecosystems and consequently protect native aquatic organisms (Richardson et al., 2005; Marczak et al., 2010; Kuglerová et al., 2014). Their biodiversity values render them as hotspots for adaptation to climate change in the near future (Das, 2014; Pandey et al., 1999). The current study is useful in filling the information gap for remote terrains, features predominant in the Himalaya, which are poorly researched due to inaccessibility. Such understanding is required for realization of the vulnerability of these systems, which are ever dynamic, and thus, necessitates the need to conduct the study at a broader scale of time and space.

\section{Conclusion}

India is endowed with a magnificent river basin network; water resources having an overriding influence on the socio-economic development of the country. This necessitates the establishment of baseline information for monitoring these systems and for developing local and national policies for guiding conservation programmes. Riverine landscapes are one of the most human-dominated areas eliciting increased developmental activities in and around the river. Dams which have comparatively larger-scale consequences, require machinery and manpower for building and maintenance, steering rapid growth of cities and settlements around; accelerating the process of habitat loss and forest fragmentation in riverine areas. Given their high productivity values and increasing degradation rates, periodic monitoring of forest fragmentation dynamics and change in land cover needs to be documented systematically and at regular time intervals. The use of satellite imageries with higher spatial/spectral resolution can aid in identifying the underlying drivers of landscape change and substantially add to such initiatives to better understand the magnitude and direction of landscape change and forest fragmentation. Delineating the rate of change from one class to another and using more comprehensive fragmentation index including patch-level analysis can aid in understanding the trends of future land use/land cover conversion to determine the resilience of these important riverine systems.

Riverine forests are fragile and have immense bio-diverse and socio-economic significance. Hydrologic alteration caused by river regulation alters the vital processes which establish and maintain riverine vegetation. The site-specific ecological consequences of natural and human induced changes remain challenging to predict and address. This is often associated with the difficulty in delineation of riparian buffers from the remaining landscape. Identifying intact forest patches of enhanced biodiversity values along the river can substantially aid in effective management and conservation. The overall trends that emerge from our study give a synoptic view of landscape change and forest fragmentation processes which can be beneficial in navigating conservation efforts towards biodiversity management at a large scale, and particularly in difficult mountain terrains predominant in the Himalaya. There is a dire need to conduct 
scientific studies on the flora and fauna of such fragmented habitats. The research can further be upgraded by understanding the underlying drivers of landscape change and potential causes of the forest fragmentation. Hence, a combination of both anthropogenic and climatic drivers can give us a holistic understanding of the actual causes underlying the fragmentation of riverine landscape features in the future. Pertinent research aiming to understand the role of fragmented vegetation in species conservation and devising novel approaches of possible restoration programmes for such fluvial landscapes is vital for future conservation.

Acknowledgements. The authors are thankful to the Department of Science and Technology, Government of India for financial assistance under the grant (SERB No: F. No. SERB/SR/SO/PS/06/2010). Thanks are due to the Uttarakhand forest department and Dr. V. B Mathur, Dr. P. K Mathur, Dr. G. S Rawat and Dr. S. Sathyakumar, Wildlife Institute of India for their support. We are grateful to Kevin Moore and Kamna Pokhariya for their assistance in analyzing the remote sensing data.

\section{REFERENCES}

[1] Alhamdan, M. Z., Oduor, P., Flores, A. I., Kotikot, S. M., Mugo, R., Ababu, J. (2017): Evaluating land cover changes in Eastern and Southern Africa from 2000 to 2010 using validated Landsat and MODIS data. - International Journal of Applied Earth Observation and Geoinformation 62: 8-26.

[2] Allen, T. R. (2000): Topographic normalization of Landsat Thematic Mapper data in three mountain environments. - Geocarto International 15: 15-22.

[3] Areendran, G., Raj, K., Mazumdar, S., Sharma, A. (2017): Land use and land cover change analysis for Kosi River wildlife corridor in Terai Arc Landscape of Northern India: Implications for future management. - Tropical Ecology 58(1).

[4] Antongiovanni, M., Metzger, J. P. (2005): Influence of matrix habitats on the occurrence of insectivorous bird species in Amazonian forest fragments. - Biological Conservation 122: 441-451.

[5] Bergkamp, G., McCartney, M., Dugan, P., McNeely, J., Acreman, M. (2000): Dams, Ecosystem Functions and Environmental Restoration. - Thematic Review II (1) prepared as an input to the World Commission on Dams, Cape Town.

[6] Bogaert, J., Barima, Y. S., Iyongo, W. M. L., Bamba, I., Mama, A., Toyi, M., Lafortezza, R. (2011): Forest Fragmentation: Causes, Ecological Impacts and Implications for Landscape Management. - In: Li, C. et al. (eds.) Landscape Ecology in Forest Management and Conservation. Challenges and Solutions for Global Change, Springer, Berlin, pp. 273-296.

[7] Census of India (2001): Government of India: New Delhi, India. http://censusindia.gov.in/ [accessed on 23 August 2017].

[8] Chen, J., Franklin, J. F., Spies, T. A. (1995): Growing-season microclimatic gradients from clearcut edges into old-growth Douglas-fir forests. - Ecological Applications 5: 7486.

[9] Das, S. (2014): Ganga - Our Endangered Heritage. - In: Sanghi, R. (ed.) Our National River Ganga. Springer International Publishing, Switzerland, pp. 45-71.

[10] Donovan, T. M., Jones, P. W., Annand, E. M., Thompson, F. R. (1997): Variation in local-scale edge effects: mechanisms and landscape context. - Ecology 78: 2064-2075.

[11] Dunning, J. B., Danielson, B. J., Pulliam, H. R. (1992): Ecological processes that affect populations in complex landscapes. - Oikos 65: 169-175. 
[12] Dybala, K. E., Matzek, V., Gardali, T., Seavy, N. E. (2019): Carbon sequestration in riparian forests: a global synthesis and meta-analysis. - Global Change Biology 25: 5767.

[13] Egbert, S. L., Park, S., Price, K. P. (2002): Using conservation reserve program maps derived from satellite imagery to characterize landscape structure. - Computer and Electronics in Agriculture 37: 141-56.

[14] Ety, N. J., Rashid, M. S. (2019): Spatiotemporal variability of erosion and accretion in Ganges River using GIS and RS: a comparative study overlapping Rennell's map of 1760s. - Environment, Development and Sustainability. https://doi.org/10.1007/s10668019-00317-4.

[15] FAO (2010): Global forest resource assessment. - Food and Agriculture Organization of the United Nations. http://www.fao.org/docrep/013/i1757e/i1757e.pdf.

[16] FSI (2015): India State of Forest Report. - Forest Survey of India, Ministry of Environment, Forest \& Climate Change, Kaulagarh Road, Dehradun. http://fsi.nic.in/forest-report-2015.

[17] Gascon, C., Lovejoy, T. E., Bierregaard Jr, R. O., Malcolm, J. R., Stouffer, P. C., Vasconcelos, H. L., Laurance, W. F., Zimmerman, B., Tocher, M., Borges, S. (1999): Matrix habitat and species richness in tropical forest remnants. - Biological Conservation 91: 223-229.

[18] Ge, H., Lu, D., He, S., Xu, A., Zhou, G., Du, H. (2008): Pixel-based Minnaert correction method for reducing topographic effects on a Landsat 7 ETM+ image. - Photogrammetric Engineering and Remote Sensing 74: 1343-1350.

[19] Gergel, S. E., Stange, Y., Coops, N. C., Johansen, K., Kirby, K. R. (2007): What is the Value of a good map? An example using high spatial resolution imagery to aid Riparian restoration. - Ecosystems 10: 688-702.

[20] Gould, W. (2000): Remote sensing of vegetation, plant species richness, and regional biodiversity hotspots source. - Ecological Applications 10: 1861-1870.

[21] Government of Uttarakhand (2014): Uttarakhand action plan on climate change'Transforming Crisis into Opportunity'. http://www.moef.gov.in/sites/default/files/Uttarakhand\%20SAPCC.pdf.

[22] Haddad, N. M., Brudvig, L. A., Clobert, J., Davies, K. F., Gonzalez, A., Holt, R. D., Lovejoy, T. E., Sexton, J. O., Austin, M. P., Collins, C. D., Cook, W. M. (2015): Habitat fragmentation and its lasting impact on Earth's ecosystems. - Science Advances 1: e1500052.

[23] Halmy, M. W. A., Gessler, P. E., Hicke, J. A., Salem, B. B. (2015): Land use/land cover change detection and prediction in the north-western coastal desert of Egypt using Markov- CA. - Applied Geography 63: 101-112.

[24] He, C., Zhang, Q., Li. Y. (2005): Zoning grassland protection area using remote sensing and cellular automata modeling- a case study in Xilingol steppe grassland in northern China. - Journal of Arid Environments 63: 814-26.

[25] Jenness, J., Wynne, J. J. (2005): Cohen's Kappa and classification table metrics 2.0: An ArcView 3. extension for accuracy assessment of spatially explicit models. - Open-File Report of 2005-1363. US Geological Survey, Southwest Biological Science Center, Flagstaff, AZ.

[26] Kaur, A., Ghosh, S., Das, S. K. (2019): Satellite image-based land use/land cover dynamics and forest cover change analysis (1996-2016) in Odisha, India. - Asian Journal of Water, Environment and Pollution 16(1): 25-39.

[27] Kuglerová, L., Ågren, A., Jansson, R., Laudon, H. (2014): Towards optimizing riparian buffer zones: ecological and biogeochemical implications for forest management. Forest Ecology and Management 334: 74-84.

[28] Lund, H. G. (1983): Change: now you see it - now you don't! - Proceedings of the International Conference on Renewable Resource Inventories for Monitoring Changes and Trends, Oregon State University, Corvallis, OR, USA 211-213. 
[29] Manel, S., Buckton, S. T., Ormerod, S. J. (2000): Testing large-scale hypotheses using surveys: the effects of land use on the habitats, invertebrates and birds of Himalayan rivers. - Journal of Applied Ecology 37: 756-770.

[30] Marczak, L. B., Sakamaki, T., Turvey, S. L., Deguise, I., Wood, S. L., Richardson, J. S. (2010): Are forested buffers an effective conservation strategy for riparian fauna? An assessment using meta-analysis. - Ecological Applications 20: 126-134.

[31] McCarthy, M. J., Radabaugh, K. R., Moyer, R. P., Muller-Karger, F. E. (2018): Enabling efficient, large-scale high spatial resolution wetland mapping using satellites. - Remote Sensing of Environment 208: 189-201.

[32] McGarigaI, K., Marks, B. J. (1994): FRAGSTATS: Spatial Pattern Analysis. Programme for Quantifying Landscape Structure. - Forest Science Department, Oregon State University, Corvallis.

[33] McGarigal, K., Marks, B. J. (1995): FRAGSTATS: Spatial Pattern Analysis Program for Quantifying Landscape Structure. - Gen. Tech. Rep. PNW-GTR-351. Portland, OR Department of Agriculture, Forest Service, Pacific Northwest Research Station 122: 351.

[34] Miles, L., Grainger, A., Phillips, O. (2004): The impact of global climate change on tropical forest biodiversity in Amazonia. - Global Ecology and Biogeography 13: 553565 .

[35] Milne, A. K. (1988): Change direction analysis using Landsat imagery: a review of methodology. - Proceedings of the IGARSS' 88 Symposium, Edinburgh, Scotland, ESA 1: $541-544$.

[36] Naiman, R. J., Decamps, H., Pollock, M. (1993): The role of Riparian corridors in maintaining regional biodiversity. - Ecological Applications 3: 209-212.

[37] Naiman, R. J., Decamps, H., McClain, M. E. (2005): Riparian Ecology, Conservation, and Management of Streamside Communities. - Elsevier Academic Press, San Diego, California, USA.

[38] Neel, M. C., McGarigal, K., Cushman, S. A. (2004): Behavior of class-level landscape metrics across gradients of class aggregation and area. - Landscape Ecology 19: 435-455.

[39] Norton, M. R., Hannon, S. J., Schmiegelow, F. K. A. (2000): Fragments are not islands: patch vs. landscape perspectives on songbird presence and abundance in a harvested boreal forest. - Ecography 23: 209-223.

[40] Osgouei, P. E., Kaya, S. (2017): Analysis of land cover/use changes using Landsat 5TMdata and indices. - Environmental Monitoring and Assessment 189(4): 136.

[41] Pandey, S. K., Singh, A. K., Hasnain, S. I. (1999): Weathering and geochemical processes controlling solute acquisition in Ganga headwater-Bhagirathi river, Garhwal Himalaya, India. - Aquatic Geochemistry 5: 357-379.

[42] Pandit, M. K., Grumbine, R. E. (2012): Potential effects of ongoing and proposed hydropower development on terrestrial biological diversity in the Indian Himalaya. Conservation Biology 26: 1061-1071.

[43] Rajvanshi, A., Arora, R., Mathur, V. B., Sivakumar, K., Sathyakumar, S., Rawat, G. S., Johnson, J. A., Ramesh, K., Dimri, N. K., Maletha, A. (2012): Assessment of Cumulative Impacts of Hydroelectric Projects on Aquatic and Terrestrial Biodiversity in Alaknanda and Bhagirathi Basins, Uttarakhand. - Technical Report, Wildlife Institute of India, Dehradun.

[44] Ramanathan, V., Chung, C., Kim, D., Bettge, T., Buja, L., Kiehl, J. T., Washington, W. M., Fu, Q., Sikka, D. R., Wild, M. (2005): Atmospheric brown clouds: impacts on south Asian climate and hydrological cycle. - Proceedings of National Academy of Sciences 102: 5326-5333.

[45] Rawat, J. S., Kumar, M. (2015): Monitoring land use/cover change using remote sensing and GIS techniques: a case study of Hawalbagh block, district Almora, Uttarakhand, India. - The Egyptian Journal of Remote Sensing and Space Sciences 18: 77-84. 
[46] Rawat, J. S., Biswas, V., Kumar, M. (2013): Changes in land use/cover using geospatial techniques-A case study of Ramnagar town area, district Nainital, Uttarakhand, India. The Egyptian Journal of Remote Sensing and Space Sciences 16: 111-117.

[47] Richardson, J. S., Naiman, R. J., Swanson, F. J., Hibbs, D. E. (2005): Riparian communities associated with Pacific Northwest headwater streams: assemblages, processes, and uniqueness. - Journal of the American Water Resources Association 41: 935-947.

[48] Rodewald, A. D., Bakermans, M. H. (2006): What is the appropriate paradigm for riparian forest conservation? - Biological Conservation 128: 193-200.

[49] Roy, A., Rathore, P. (2019): Western Himalayan Forests in Climate Change Scenario. In: Navalgund, R. R. et al. (eds.) Remote Sensing of Northwest Himalayan Ecosystems. Springer, Singapore, pp. 265-283.

[50] Roy, P. S., Roy, A. (2010): Land use and land cover change in India: a remote sensing \& GIS perspective. - Journal of the Indian Institute of Science 90: 489-502.

[51] Roy, P. S., Murthy, M. S. R., Roy, A., Kushwaha, S. P. S., Singh, S., Jha, C. S., Behera, M. D., Joshi, P. K., Jagannathan, C., Karnatak, H. C., Saran, S. (2013): Forest fragmentation in India. - Current Science 105: 774-780.

[52] Shawul, A. A., Chakma, S. (2019): Spatiotemporal detection of land use/land cover change in the large basin using integrated approaches of remote sensing and GIS in the Upper Awash basin, Ethiopia. - Environmental Earth Sciences 78(5): 141.

[53] Silva, T. S., Costa, M. P., Melack, J. M., Novo, E. M. (2008): Remote sensing of aquatic vegetation: theory and applications. - Environmental Monitoring and Assessment 40: 131-145.

[54] Solbrig, O. T. (1992): The IUBS-SCOPE-UNESCO programme of research in biodiversity. - Ecological Applications 2: 131-8.

[55] Steel, E. A., Hughes, R. M., Fullerton, A. H., Schmutz, S., Young, J. A., Fukushima, M., Muhar, S., Poppe, M., Feist, B. E., Trautwein, C. (2010): Are we meeting the challenges of landscape-scale riverine research? A review. - Living Reviews in Landscape Research 4: $1-60$.

[56] Stella, J. C., Bendix, J. (2019): Multiple Stressors in Riparian Ecosystems. In: Sabater, S. et al. (eds.) Multiple Stressors in River Ecosystems - Elsevier, Amsterdam, pp. 81-110.

[57] Sutfin, N. A., Wohl, E. E., Dwire, K. A. (2016): Banking carbon: a review of organic carbon storage and physical factors influencing retention in floodplains and riparian ecosystems. - Earth Surface Processes and Landforms 41: 38-60.

[58] Tomscha, S. A., Gergel, S. E., Tomlinson, M. J. (2017): The spatial organization of ecosystem services in river-floodplains. - Ecosphere 8: e01728.

[59] Vani, M., Prasad, P. R. C. (2019): Assessment of spatio-temporal changes in land use and land cover, urban sprawl, and land surface temperature in and around Vijayawada city, India. - Environment, Development and Sustainability. https://doi.org/10.1007/s10668019-00335-2.

[60] Villard, M. A., Trzcinski, M. K., Merriam, G. (1999): Fragmentation effects on forest birds: relative influence of woodland cover and configuration on landscape occupancy. Conservation Biology 13: 774-783.

[61] Ward, J. V., Malard, F., Tockner, K (2002): Landscape ecology: a framework for integrating pattern and process in river corridors. - Landscape Ecology 17: 35-45.

[62] Wilson, C. O., Liang, B., Rose, S. J. (2018): Projecting future land use/land cover by integrating drivers and plan prescriptions: the case for watershed applications. - GIS Science \& Remote Sensing 56(4): 511-535.

[63] Wilson, E. (1992): The Diversity of Life. - W. W. Norton \& Company, New York.

[64] Wong, C. M., Williams, C. E., Pittock, J., Collier, U., Schelle, P. (2007): World's Top Ten Rivers at Risk. - WWF International, Gland, Switzerland. assets.panda.org/downloads/worldstop10riversatriskfinalmarch13.pdf. 
[65] Woodroffe, R., Ginsberg, J. R. (1998): Edge effects and the extinction of populations inside protected areas. - Science 280: 2126-2128.

[66] Xie, Y., Sha, Z., Yu, M. (2008): Remote sensing imagery in vegetation mapping: a review. - Journal of Plant Ecology 1: 9-23.

[67] Xu, J., Grumbine, R. E., Shrestha, A., Eriksson, M., Yang, X., Wang, Y. U. N., Wilkes, A. (2009): The melting Himalayas: cascading effects of climate change on water, biodiversity and livelihoods. - Conservation Biology 24: 520-530.

\section{APPENDIX}

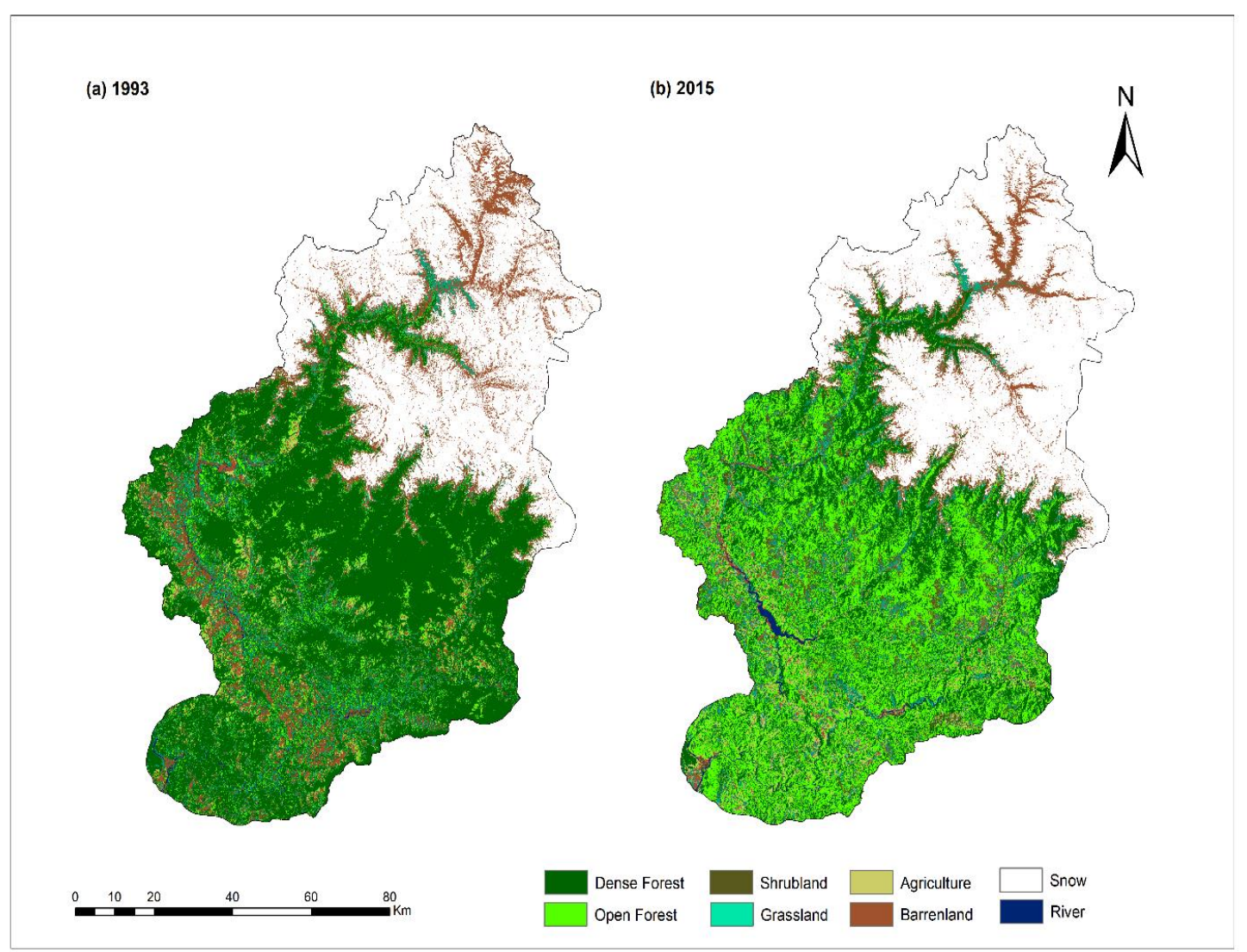

Figure A1. Land cover maps depicting temporal change ( $a$ : 1993 and $b: 2015)$ in the eight land cover types namely, dense forest, open forest, shrubland, grassland, agriculture, barren land, snow and river) of the Bhagirathi basin. 
Table A1. Percentage landscape change of eight land cover classes from 1993 to 2015 in the 123 buffer unit (area $=4 \mathrm{~km}^{2}$ each) $\mathrm{s}$ along the river Bhagirathi

\begin{tabular}{|c|c|c|c|c|c|c|c|c|}
\hline $\begin{array}{c}\text { Buffer } \\
\text { units }\end{array}$ & $\begin{array}{l}\text { Dense } \\
\text { forest }\end{array}$ & $\begin{array}{l}\text { Open } \\
\text { forest }\end{array}$ & Shrubland & Grassland & Agriculture & $\begin{array}{c}\text { Barren } \\
\text { land }\end{array}$ & Snow & River \\
\hline 1 & -16.3 & -1.3 & -16.4 & 4.9 & 13.0 & 16.0 & 0.0 & 0.2 \\
\hline 2 & 0.1 & -0.3 & -0.2 & 0.4 & 0.0 & -11.5 & 11.5 & 0.0 \\
\hline 3 & 0.9 & -3.2 & -1.3 & -3.3 & 0.0 & -1.6 & 8.5 & 0.0 \\
\hline 4 & -11.0 & -7.6 & -3.6 & 8.7 & 1.0 & 5.4 & 7.1 & 0.0 \\
\hline 5 & -0.8 & -9.9 & -3.3 & 6.2 & 0.6 & 2.2 & 5.0 & 0.0 \\
\hline 6 & 22.6 & -15.7 & -2.9 & -9.6 & 0.9 & 1.6 & 3.0 & 0.0 \\
\hline 7 & 12.5 & -10.1 & -5.1 & 4.7 & 0.9 & -3.4 & 0.5 & 0.0 \\
\hline 8 & 14.0 & -7.7 & -4.3 & -1.9 & 2.5 & -3.5 & 1.0 & 0.0 \\
\hline 9 & 10.3 & -8.0 & -4.5 & 2.4 & 2.5 & -2.7 & 0.0 & 0.0 \\
\hline 10 & 21.3 & -10.9 & -5.6 & -8.7 & 3.1 & 0.7 & 0.0 & 0.0 \\
\hline 11 & 11.3 & -7.1 & -6.2 & -2.7 & 3.2 & -0.1 & 0.2 & 1.4 \\
\hline 12 & 10.8 & -3.6 & -2.6 & -6.2 & 1.0 & -1.3 & 0.0 & 1.8 \\
\hline 13 & 11.2 & -2.2 & -3.7 & -5.4 & 2.0 & -2.2 & 0.0 & 0.2 \\
\hline 14 & 4.6 & 0.2 & -2.4 & -3.3 & 2.1 & -1.4 & 0.0 & 0.1 \\
\hline 15 & -6.2 & 8.2 & -3.2 & -0.9 & 3.3 & -1.7 & 0.0 & 0.6 \\
\hline 16 & -9.8 & 10.0 & -6.8 & -1.5 & 6.3 & -0.1 & -0.4 & 2.4 \\
\hline 17 & -3.0 & 4.0 & -9.2 & -0.2 & 9.4 & -2.8 & -2.1 & 4.0 \\
\hline 18 & -9.5 & 8.4 & -10.6 & 2.7 & 10.6 & -2.7 & -1.0 & 2.1 \\
\hline 19 & -4.1 & 0.3 & -5.9 & 7.9 & 4.9 & -4.6 & -0.7 & 2.1 \\
\hline 20 & 5.5 & -4.9 & -12.4 & 4.3 & 12.2 & -6.3 & -1.8 & 3.4 \\
\hline 21 & 9.5 & -9.7 & -15.1 & 12.0 & 13.4 & -10.3 & -1.1 & 1.4 \\
\hline 22 & 4.9 & -6.8 & -18.8 & 16.5 & 12.2 & -9.8 & -0.9 & 2.6 \\
\hline 23 & -1.4 & -6.5 & -2.8 & 10.6 & 2.4 & -3.2 & 0.4 & 0.5 \\
\hline 24 & -16.1 & 5.1 & -5.8 & 11.3 & 6.8 & -1.9 & 0.0 & 0.6 \\
\hline 25 & -13.1 & -0.8 & -3.3 & 15.2 & 4.2 & -1.5 & 0.0 & -0.8 \\
\hline 26 & -7.4 & 0.4 & -6.6 & 10.4 & 8.5 & -5.9 & 0.0 & 0.6 \\
\hline 27 & -20.0 & 1.6 & 5.2 & 11.0 & 5.2 & -2.1 & 0.0 & -0.9 \\
\hline 28 & -18.9 & -0.5 & 6.9 & 11.2 & 0.2 & 1.4 & 0.0 & -0.2 \\
\hline 29 & -28.8 & 0.5 & -1.0 & 24.8 & 5.0 & -0.4 & 0.0 & 0.0 \\
\hline 30 & -23.7 & 16.4 & -7.4 & 7.9 & 7.4 & -0.4 & 0.0 & -0.3 \\
\hline 31 & -22.1 & 23.9 & -9.7 & 3.3 & 3.6 & 1.0 & 0.0 & -0.1 \\
\hline 32 & -24.5 & 1.8 & 1.1 & 17.3 & 3.2 & 0.9 & 0.0 & 0.1 \\
\hline 33 & -21.9 & 0.8 & 13.5 & 17.5 & -11.5 & 1.1 & 0.0 & 0.6 \\
\hline 34 & -14.0 & 11.6 & 10.1 & 16.9 & -19.7 & -3.7 & 0.0 & -1.3 \\
\hline 35 & -21.7 & 16.5 & 15.8 & 24.1 & -26.8 & -8.5 & 0.0 & 0.7 \\
\hline 36 & -21.9 & 17.8 & 6.3 & 16.4 & -19.4 & 1.1 & 0.0 & -0.4 \\
\hline 37 & -29.4 & 22.8 & -3.7 & 21.2 & -11.2 & 0.6 & 0.0 & -0.3 \\
\hline 38 & -31.5 & 9.7 & 1.5 & 18.5 & -0.9 & 2.9 & 0.0 & -0.1 \\
\hline 39 & -15.3 & 5.8 & 0.0 & 4.2 & 2.9 & 3.2 & 0.0 & -0.7 \\
\hline 40 & -9.5 & 14.9 & -8.6 & -4.9 & 5.1 & 4.6 & 0.0 & -1.6 \\
\hline 41 & 19.0 & -7.3 & -10.8 & -6.1 & 4.7 & 1.1 & 0.1 & -0.8 \\
\hline 42 & -5.4 & 2.6 & -6.6 & 7.7 & 3.2 & -0.9 & 0.0 & -0.5 \\
\hline
\end{tabular}




\begin{tabular}{|c|c|c|c|c|c|c|c|c|}
\hline 43 & 27.4 & 11.0 & -22.3 & -19.4 & 4.5 & -0.4 & 0.0 & -0.9 \\
\hline 44 & 15.2 & 2.5 & -15.9 & -6.5 & 3.7 & 1.0 & 0.0 & -0.1 \\
\hline 45 & 23.5 & -9.1 & -7.5 & 6.4 & -5.0 & -7.8 & 0.0 & -0.6 \\
\hline 46 & 28.7 & 1.5 & -9.4 & -9.5 & 5.2 & -18.5 & 0.0 & 2.0 \\
\hline 47 & 29.9 & 15.6 & -7.1 & -1.8 & -31.3 & -6.3 & 0.0 & 1.0 \\
\hline 48 & 18.0 & 18.5 & -13.4 & 3.2 & -2.8 & -24.8 & 0.0 & 1.3 \\
\hline 49 & 20.5 & 6.2 & -11.6 & -4.1 & 7.1 & -11.0 & 0.0 & -7.2 \\
\hline 50 & -0.7 & 8.6 & -13.8 & 5.3 & 3.2 & -3.2 & 0.0 & 0.5 \\
\hline 51 & 18.4 & -0.7 & -22.2 & 3.7 & 5.0 & -2.9 & 0.0 & -1.3 \\
\hline 52 & 16.0 & 4.5 & -6.7 & -8.0 & 8.5 & -13.3 & 0.0 & -1.1 \\
\hline 53 & 26.8 & -2.1 & -12.0 & -8.9 & 4.6 & -5.5 & 0.0 & -2.8 \\
\hline 54 & 21.2 & 2.3 & -23.2 & -5.6 & 13.5 & -6.9 & 0.0 & -1.3 \\
\hline 55 & 20.3 & 9.9 & -43.6 & -1.2 & 21.3 & -6.0 & 0.0 & -0.7 \\
\hline 56 & 26.5 & -8.4 & -22.1 & -3.8 & 6.7 & 1.9 & 0.0 & -0.9 \\
\hline 57 & 25.2 & -2.7 & -23.6 & -4.1 & 5.8 & 1.7 & 0.0 & -2.3 \\
\hline 58 & 12.5 & 13.5 & -22.6 & -18.3 & 14.0 & 2.4 & 0.0 & -1.6 \\
\hline 59 & 25.6 & 3.6 & -20.7 & -15.7 & 8.9 & 1.3 & 0.0 & -3.0 \\
\hline 60 & 8.1 & 15.2 & -20.1 & -4.6 & 4.8 & -2.7 & 0.0 & -0.7 \\
\hline 61 & 3.3 & 9.2 & -14.4 & -6.1 & 4.4 & 4.5 & 0.1 & -1.1 \\
\hline 62 & 8.2 & 15.1 & -30.6 & -10.6 & 10.6 & 7.0 & 0.0 & 0.2 \\
\hline 63 & 10.7 & 12.8 & -30.8 & -7.3 & 15.8 & -2.5 & 0.0 & 1.2 \\
\hline 64 & 17.3 & 2.7 & -36.2 & -4.7 & 16.7 & 2.3 & 0.0 & 2.1 \\
\hline 65 & 9.3 & 7.2 & -43.4 & -9.9 & 13.0 & 18.1 & 0.0 & 5.7 \\
\hline 66 & 7.5 & 0.4 & -32.8 & 3.8 & 9.8 & -0.8 & 0.0 & 12.0 \\
\hline 67 & 10.9 & 4.5 & -35.1 & -3.5 & 14.4 & -0.8 & 0.0 & 9.6 \\
\hline 68 & 12.1 & -10.7 & -22.1 & -5.4 & 7.4 & 4.3 & 0.0 & 14.5 \\
\hline 69 & 11.7 & -7.0 & -25.9 & -14.2 & 17.6 & 3.7 & 0.0 & 14.1 \\
\hline 70 & 10.4 & -4.7 & -24.1 & -9.3 & 14.3 & -2.9 & 0.0 & 16.3 \\
\hline 71 & 3.2 & 10.1 & -39.4 & -22.2 & 10.9 & 6.3 & 0.0 & 31.2 \\
\hline 72 & 19.3 & 8.6 & -35.3 & -8.4 & -1.1 & -10.3 & 0.0 & 27.3 \\
\hline 73 & 6.7 & 7.1 & -27.9 & -13.4 & -0.5 & -12.2 & 0.0 & 40.3 \\
\hline 74 & 3.4 & 2.4 & -24.0 & -21.5 & -5.3 & -25.1 & 0.0 & 70.1 \\
\hline 75 & -2.2 & 2.5 & -10.0 & -21.9 & -6.4 & -28.6 & 0.0 & 66.6 \\
\hline 76 & -2.2 & 5.5 & -18.5 & -17.0 & 3.4 & -20.0 & 0.0 & 48.8 \\
\hline 77 & 0.3 & 11.7 & -9.4 & -2.6 & 3.2 & 2.3 & 0.0 & -5.4 \\
\hline 78 & 3.7 & 7.1 & -20.1 & 0.3 & 14.8 & -7.3 & 0.0 & 1.5 \\
\hline 79 & 7.0 & 6.8 & -21.8 & -0.4 & 14.6 & -8.6 & 0.0 & 2.4 \\
\hline 80 & 2.4 & 5.9 & -16.9 & -0.7 & 8.7 & -3.3 & 0.0 & 3.8 \\
\hline 81 & -39.0 & 38.0 & -8.8 & -5.6 & 8.7 & 0.1 & 0.0 & 6.6 \\
\hline 82 & -10.9 & 9.3 & -11.3 & -6.9 & 8.9 & 0.1 & 0.0 & 10.8 \\
\hline 83 & -22.0 & 12.7 & -3.7 & -1.0 & 3.7 & 0.7 & 0.0 & 9.6 \\
\hline 84 & -17.6 & 4.2 & -7.7 & -6.2 & 11.2 & 5.0 & 0.0 & 11.1 \\
\hline 85 & -9.3 & 12.3 & -8.5 & -5.3 & 9.1 & -0.5 & 0.0 & 2.2 \\
\hline 86 & -33.8 & 41.9 & -2.7 & -8.2 & 3.7 & -0.2 & 0.0 & -0.7 \\
\hline 87 & -13.2 & 24.8 & -15.1 & -11.7 & 18.0 & -2.3 & 0.0 & -0.5 \\
\hline 88 & -7.8 & 21.4 & -10.8 & -12.5 & 16.2 & -6.6 & 0.0 & 0.0 \\
\hline
\end{tabular}




\begin{tabular}{l|c|c|c|c|c|c|c|c}
89 & 8.8 & 0.8 & -5.6 & -2.0 & 7.0 & -8.7 & 0.0 & -0.3 \\
90 & -10.6 & 29.9 & -9.5 & -21.8 & 12.1 & -0.7 & 0.0 & 0.5 \\
91 & 7.6 & -0.3 & -5.6 & -12.6 & 10.5 & 0.5 & 0.0 & -0.2 \\
92 & 18.2 & -5.9 & -13.3 & -15.2 & 20.0 & -4.0 & 0.0 & 0.1 \\
93 & 13.5 & -9.1 & -14.3 & -2.0 & 17.4 & -4.6 & 0.0 & -1.0 \\
94 & -2.7 & 13.1 & -16.7 & -5.4 & 19.9 & -7.2 & 0.0 & -0.9 \\
95 & -11.9 & 27.2 & -16.9 & -12.0 & 19.2 & -6.6 & 0.0 & 1.0 \\
96 & -17.1 & 38.8 & -11.7 & -23.2 & 14.3 & -2.3 & 0.0 & 1.1 \\
97 & -18.5 & 28.1 & -7.2 & -12.3 & 10.1 & -1.8 & 0.0 & 1.5 \\
98 & -20.7 & 54.8 & -13.3 & -31.9 & 14.4 & -3.3 & 0.0 & 0.1 \\
99 & -35.7 & 39.1 & -3.0 & -8.8 & 8.0 & -0.8 & 0.0 & 1.3 \\
100 & -23.8 & 22.3 & -1.0 & -5.7 & 4.5 & 0.4 & 0.0 & 3.3 \\
101 & -29.6 & 34.0 & -1.5 & -7.1 & 5.2 & -0.9 & 0.0 & 0.0 \\
102 & -32.7 & 42.6 & -2.0 & -12.1 & 4.5 & -0.5 & 0.0 & 0.3 \\
103 & -32.6 & 40.2 & -4.6 & -8.7 & 6.8 & -1.3 & 0.0 & 0.2 \\
104 & -21.6 & 29.2 & -2.7 & -12.5 & 8.1 & -0.4 & 0.0 & -0.1 \\
105 & -19.7 & 28.1 & -2.5 & -16.6 & 11.0 & -0.5 & 0.0 & 0.1 \\
106 & -11.7 & 17.5 & -3.8 & -12.7 & 11.0 & 0.7 & 0.0 & -1.1 \\
107 & -28.0 & 27.9 & -3.9 & -8.4 & 13.8 & -1.4 & 0.0 & 0.0 \\
108 & -15.0 & 21.6 & -6.9 & -18.7 & 19.1 & 0.4 & 0.0 & -0.5 \\
109 & -44.7 & 47.2 & -3.8 & -5.5 & 7.3 & -0.2 & 0.0 & -0.2 \\
110 & -45.3 & 46.0 & -2.8 & -4.9 & 7.3 & -0.1 & 0.0 & -0.3 \\
111 & -35.8 & 32.2 & -6.3 & -1.6 & 11.3 & 0.4 & 0.0 & -0.2 \\
112 & -49.0 & 42.8 & -4.8 & -4.9 & 13.4 & 2.9 & 0.0 & -0.4 \\
113 & -45.6 & 41.8 & -3.8 & -3.7 & 10.7 & 0.6 & 0.0 & 0.1 \\
114 & -44.4 & 45.2 & -2.1 & -3.4 & 4.7 & 0.1 & 0.0 & 0.0 \\
115 & -39.2 & 35.0 & -1.6 & -6.8 & 11.1 & 1.5 & 0.0 & 0.0 \\
116 & -46.2 & 46.9 & -1.9 & -6.3 & 7.2 & 1.7 & 0.0 & -1.5 \\
117 & -48.7 & 51.3 & -1.2 & -3.1 & 3.0 & -0.6 & 0.0 & -0.7 \\
118 & -38.3 & 43.0 & -2.0 & -14.0 & 11.7 & 0.7 & 0.0 & -1.1 \\
119 & -16.4 & 17.3 & -12.2 & -9.3 & 15.7 & 6.5 & 0.0 & -1.6 \\
120 & -19.2 & 16.7 & -9.9 & -10.1 & 15.8 & 7.0 & 0.0 & -0.4 \\
121 & -9.1 & 6.5 & -11.1 & -6.8 & 10.5 & 9.7 & 0.0 & 0.3 \\
122 & -2.9 & -5.5 & -10.9 & 4.9 & -2.7 & 16.2 & 0.0 & 0.9 \\
123 & -6.7 & -11.2 & -24.2 & 9.5 & 2.9 & 28.2 & 0.0 & 1.5 \\
\hline
\end{tabular}

